\title{
Effect of Air Pollution on Human Health in Manufacturing Industries at SITE Area, Hyderabad
}

\author{
Danish Ali Memon ${ }^{1}$, Khan Muhammad Brohi' ${ }^{2}$ Muhammad Aamir Panhwar', \\ Afaque Rafique Memon ${ }^{4}$ and Aqeel Ahmed Bhutto ${ }^{1}$
}

\begin{abstract}
'Mechanical and Manufacturing Engineering, Universiti Tun Hussein Onn Malaysia (UTHM), Johor, Malaysia / Department of Mechanical Engineering, Mehran University of

Engineering and Technology, SZAB Campus, Khairpur Mirs, 66020, Sindh,

Pakistan; danishmemon2013@yahoo.com, aqeelbhutto03@yahoo.com

${ }^{2}$ Institute of Environmental Engineering and Management, Mehran University of

Engineering and Technology Jamshoro, 76020, Sindh, Pakistan;

khan.brohi@faculty.muet.edu.pk

${ }^{3}$ School of Electronic Engineering, Beijing University of Posts and Telecommunications,

China / Department of Biomedical Engineering, Mehran University of Engineering and Technology, Jamshoro, 76020, Sindh, Pakistan; maamirpanhwar@gmail.com

${ }^{4}$ Institute of Bio-medical Manufacturing and Life quality Engineering, School of

Mechanical Engineering, Shanghai Jiaotong University, shanghai,
\end{abstract}

China; afaque@sjtu.edu.cn

\begin{abstract}
Background/Objectives: Hyderabad comes as a major industrial city in Pakistan, which covers more than 1264 acres of land surrounded by industries. This big city is facing extreme air pollution problems. However, this study was carried out to evaluate the health problems caused by polluted air in Industrial SITE Area of Hyderabad. Methods/Statistical Analysis: Two different Questionnaires were carried out to conduct a survey, first one for basic health unit purpose at the clinic level and second for workers to observe any curious diseases relating to air pollution. Findings: Labors have $24 \%$ Cough, $18 \%$ Dermatitis, 8\% Exacerbation of asthma and 7\% acute respiration inspection. In addition, huge negligence of following safety measures was also observed during the survey. Most of the workers were not using any personal protective equipment and were lacking awareness. Application/ Improvements: It is strongly recommended to follow safety rules and regulations at the workplace, enhance the trees plantation and air pollution equipment must be instated by industries.
\end{abstract}

Keywords: Air Pollution, Diseases, Impact on Health and Hyderabad City, Industries

\section{Introduction}

Air pollution has remained as a major unease to public health throughout the world; especially it has appeared as serious threatening issue that is faced by the developing countries ${ }^{1}$. The European developed countries and states of United States of America (USA) have suffered severe environmental problems due to air pollution. If we compare current scenario of environmental problems caused by air pollution in developing countries with developed countries that had initiated industrialization many decades ago. The environmental problem caused by air pollution of current developing are more severe due to encroachment of forests, massive use of fossil fuels and energy consumption, demolishment rural areas to urbanization, reconstructions of high

${ }^{*}$ Author for correspondence 
rise buildings and excessive use of smoke emitting transportations. Developed which were developed and developing countries ${ }^{2}$. A report published by World Health Organization (WHO) in 2008, air pollution resulted as reason of 3 million deaths globally. Other report of 2012 figured increase in deaths to 3.7 million. It is not just industrialization but according to WHO report household air pollution has severe effects and it has resulted Two million deaths in 2008. The number of deaths has increased to 4.3 million in $2012^{3}$. Air pollution is being the sole reason to premature deaths of 2 million peoples each year globally. According to report of 2012, 7 million deaths were caused due to household and ambient air pollution ${ }^{4}$.

\section{The Health Risks of Air Pollution}

The pollutated air is hazordous to our health. It can cause a number serious disease that can effect us in long and short term. The impact of polluted air could vary in according to age groups and their immunity level. The less immune age group like young children and elderly people are most likely to get more effected from air pollution. People already having disease like lung, asthama and heart diseases are more likely to suffer in polluted air. The polluted air carries

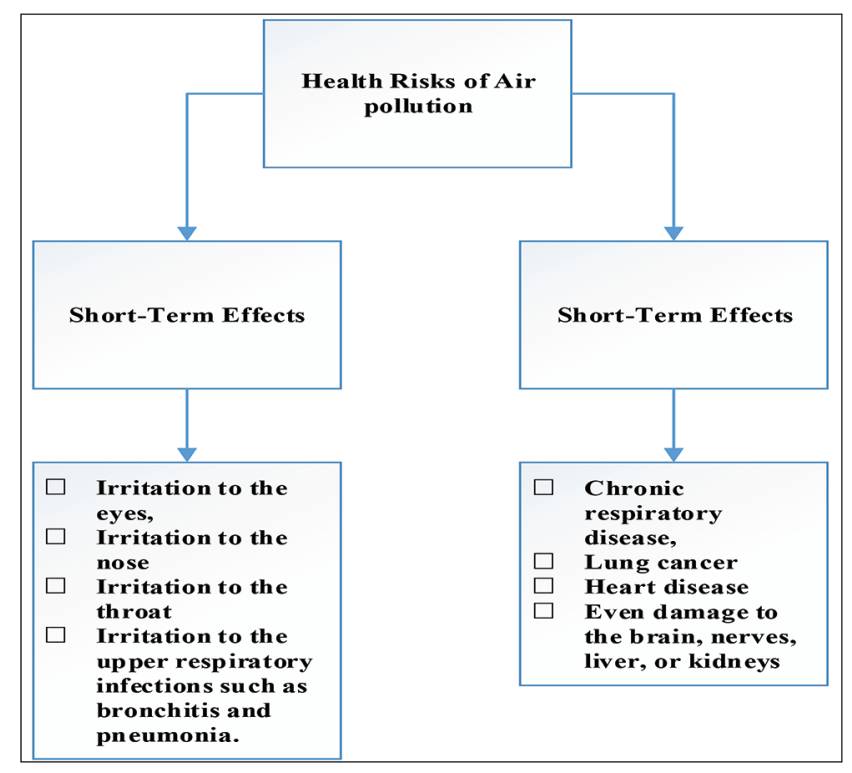

Figure 1. Risk of air pollution on human health interm of short and long term effect. damagining chemicals that can cause harm to any individul.

Nonetheless, it is not a matter whether the person is sustaining the air pollution either for short time or for long time. Both have it is own effects on the health of vicinity people.

Figure 1 shows the examples of short-term effects include irritation to the eyes, nose, and throat, and upper respiratory infections such as bronchitis and pneumonia. Other symptoms can include headaches, nausea, and allergic reactions. Short-term air pollution can aggravate the medical conditions of individuals with asthma and emphysema 5,6 . When London was affected by smog in 1952, four thousand people died in a few days due to the high concentrations of pollution Long-term health effects can include chronic respiratory disease, lung cancer, heart disease, and even damage to the brain, nerves, liver, or kidneys. Continual exposure to air pollution affects the lungs of growing children and may aggravate or complicate medical conditions in the elderly ${ }^{7}, \underline{8}$.

A normal human inhales $16 \mathrm{~kg}$ of air and breathes around 22,000 per day 210 . The clean that we breathe is life supporting. However, contaminants present in the air often cause injurious effects. These pollutants are mixer of different concentration and major expose to such nature of pollutants will cause medical issue to human health $\underline{11}$. The immune system of infants and elderly people is weak due to which they are most risk in such polluted environment. Further, winter weather has more has maximum adverse health effects of air pollutants in comparison to other seasons ${ }^{12}$. Few of the most common and vital air pollutants that affect human health are shown in Table 1. Sulfur dioxide is characterized as the most hazardous pollutant gas to human. A number of industries emits this gas and causes numerous respiratory disorders. Oxides of nitrogen and carbon monoxide decrease the supply of $\mathrm{O} 2$ to the tissues. Lead pollution is type metal poisoning that damages the tissue and results several pattern of abnormal behavior. Suspended Particulate Matter (SPM) mainly causes chronic pulmonary diseases. Lengthy exposure to radioactive isotopes results in anemia; also, it has a heavy risk of cancer and genetic defects.

There are two main reasons to the pollution of the air, which are described as follows: 
Table 1. Health effect from different air pollutant

\begin{tabular}{|l|l|}
\hline Pollutant & Effects \\
\hline Sulfur dioxide $\left(\mathrm{SO}_{2}\right)$ & $\begin{array}{l}\text { Nose and Throat irritation } \\
\text { respiratory illness, Prolonged } \\
\text { exposure may lead to chronic } \\
\text { bronchitis }\end{array}$ \\
\hline $\begin{array}{l}\text { Nitrogen dioxide }\left(\mathrm{NO}_{2}\right) \\
\text { and Nitric oxide }(\mathrm{NO})\end{array}$ & $\begin{array}{l}\text { Irritation of eyes, nose, and } \\
\text { throat. NO combine with } \mathrm{O}_{2} \\
\text { and reduce the supply of } \mathrm{O}_{2} \text { to } \\
\text { tissues. }\end{array}$ \\
\hline Carbon monoxide $(\mathrm{CO})$ & $\begin{array}{l}\text { Binds to hemoglobin and } \\
\text { drastically reduces } \mathrm{O}_{2} \text { supply } \\
\text { to tissues. May result in } \\
\text { cardiovascular and pulmonary } \\
\text { diseases. }\end{array}$ \\
\hline $\begin{array}{l}\text { Heavy Metal }(\mathrm{Pb}) \\
\left(\mathrm{I}^{131}, \mathrm{P}^{32}, \mathrm{Co}{ }^{60}\right)\end{array}$ & $\begin{array}{l}\text { Damage to Liver, kidney, } \\
\text { and brain: causes anemia, } \\
\text { neurobehavioral changes, and } \\
\text { abnormalities in fertility and } \\
\text { pregnancy. }\end{array}$ \\
\hline $\begin{array}{l}\text { Aliphatic hydrocarbons } \\
\text { and Polycyclic organic } \\
\text { compounds }\end{array}$ & $\begin{array}{l}\text { Anemia, cancer and genetic } \\
\text { defects }\end{array}$ \\
\hline $\begin{array}{l}\text { Suspended Particulate } \\
\text { Matter }(\mathrm{SPM})\end{array}$ & $\begin{array}{l}\text { Chronic Pulmonary disease, } \\
\text { bronchitis, asthma. }\end{array}$ \\
\hline adioactive isotopes & \\
\hline
\end{tabular}

Sources of Air pollution.

\subsection{Natural Sources}

These include volcanic eruptions, sandstorms, and decomposition of organic matter, forest fire, pollen grains, and cosmic dust. The problem of pollution due to natural sources, in general, is considered minimal.

\subsection{Anthropogenic (man-made) Sources}

Air pollution due to human-induced activities is very high. The causes of pollution include industries, burning of fossil fuels, emissions from vehicles, agricultural activities, andwarfares. The sources of air pollution may also consider as stationary (industries, open combustion) or mobile (motor vehicles, trains, and aircraft) in nature.

Industrial pollutants: The major problem of air pollution is due to industrial activities. Among the several industries, nine types of industries are considered the major air pollutant is generating industries (Table 4). Among these, thermal power plants, steel industries, petroleum refineries, and metal smelters are the most dangerous polluting industries ${ }^{\underline{13}}$.

\section{Industrial Pollutants}

This industrialization has played a vital role in polluting air. These industries emit smoke fully concentrated with chemical and they drain chemical on the name of waste that pollute the land. Amongst the numerous industries, normally fewer than nine types of industries are paying the main cause for air pollutant (Table 2). Petroleum refineries thermal power plants metal smelters and steel industries are the hazardous most polluting industries ${ }^{14}$.

Table 2. Major Industrial sources air pollution

\begin{tabular}{|l|l|}
\hline Industry & Major Air Pollutant \\
\hline Thermal Power Plant & $\mathrm{NO}_{2}, \mathrm{~N}_{2} \mathrm{O}, \mathrm{SO}_{2}$ \\
\hline Steel Industries & $\begin{array}{l}\text { Smoke, Particulates, } \mathrm{CO}_{2} \\
\text { Fluoride }\end{array}$ \\
\hline Petroleum Refineries & Smoke, Particulates, $\mathrm{SO}_{2}$ \\
\hline Metal Smelters & $\begin{array}{l}\text { Smoke, Particulates, } \mathrm{NO}_{2}, \mathrm{~N}_{2} \mathrm{O}, \\
\mathrm{SO}_{2}\end{array}$ \\
\hline Fertilizer Plant & $\mathrm{NO}_{2}, \mathrm{~N}_{2} \mathrm{O}, \mathrm{SO}_{2}$ \\
\hline Acid Plant & $\mathrm{NO}_{2}, \mathrm{~N}_{2} \mathrm{O}, \mathrm{SO}_{2}$ \\
\hline Cement Plant & Smoke, Particulates, $\mathrm{SO}_{2}$ \\
\hline Soap and detergent Plants & Particulates, Odour \\
\hline Paper Mills & Particulates, Odour $\mathrm{SO}_{2}$ \\
\hline
\end{tabular}

\section{Methodology for Health Impact Assessment}

A quantitative researh desgin has been adopted for the evaluation of air pollution impacts on the population health in SITE area Hyderabad, Sindh. However, there are several industries working in hyderabad area but this study focuse only metal, glass and power gerneration plant. Two types questionnaires were employed for quantitative data collection from medical doctors at clinic level and industrial workers/ staffs. Whereas, currently 36 industries (metal, glass and power gerneration plant) and 8 clinics are working in which total 3,500 employees are working. While, this research study was selected random sampling for quantitative data collection. According to the table or formula Karejcie and morgan $\frac{15}{15}$, there are required rate 346 sample size for data collection. 
Therefore, 750 questionnairs were distributed to the respondents (doctors and Industries' staff). The questionnaires were aqurately compiled return by the 346 respondents. Furthermore, the percentage frequency method was adopted to identifty which diseases more effected by the air pollution and how many workers aware by the protection of health and safety regarding air pollution. For this purpose the SPSS software version 23.0 is used. The study methodology is given in flowchart as shown in Figure 2.

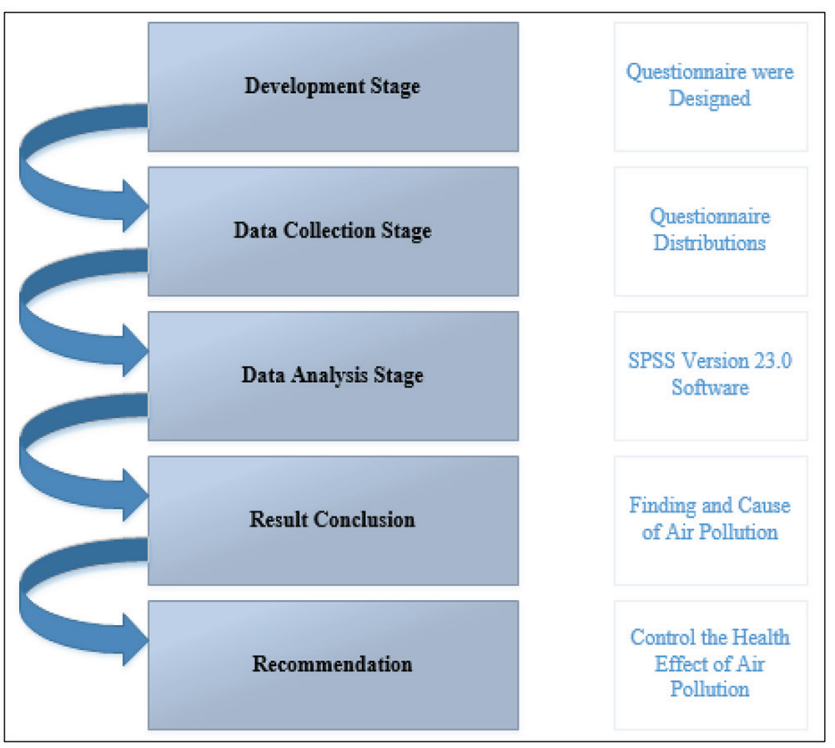

Figure 2. Flowchart for Study Methodology

\subsection{Questionnaires}

To understand the impact of air pollution we conducted a survey in the vicinity of SITE area. To understand the condition a questanior was designed and distributed for the feedback from the residents,workers and staff of different industries at SITE area Hyderabad. Additionally, an elaborated list has been designed in concentation with the field oriented experts and was filled by asking the different questions from the people living in the vicinity area. The questionnaires related to air pollution are given in Table 3-5.

Whereas Table 3 relating to air pollution disease, Table 4 general aspect for air pollution and Table 5 was assigned to get a response from medical clinicsin the vicinity area.

\section{Results and Discussion}

Table 3 shows the doctor survey report ofgeneral diseases regarding air pollution to the community living in the vicinity of SITE area Hyderabad. It shows $24 \%$ cough, $18 \%$ Dermatitis, 8\% Exacerbation of asthma and7\% Impaired Neuropsychological development in children. The diseases are a major contribution of air pollution and furthermore its is illustrated in Table 3.

Table 3. Diseases of air pollution

\begin{tabular}{|l|c|}
\hline \multicolumn{1}{|c|}{ List of disease due to air Pollution } & Patient (\%) \\
\hline A cough & 24 \\
\hline Acute respiratory infections & 7 \\
\hline Bronchial hyperactivity & 3 \\
\hline Bronchiolitis obliterans & 1 \\
\hline Broncho-constriction & 2 \\
\hline Carcinoma of lungs & 5 \\
\hline Conjunctivitis & 5 \\
\hline $\begin{array}{l}\text { COPD (Chronic Obstructive Pulmonary } \\
\text { Diseases) }\end{array}$ & 3 \\
\hline Decreased exercise performance & 6 \\
\hline Dermatitis & 18 \\
\hline Emphysema & 2 \\
\hline Exacerbation of asthma & 8 \\
\hline Impaired lung defenses & 1 \\
\hline $\begin{array}{l}\text { Impaired Neuropsychological } \\
\text { development in children. }\end{array}$ & 7 \\
\hline Pneumoconiosis & 1 \\
\hline Pneumonia & 2 \\
\hline Respiratory tract irritation & 2 \\
\hline Sub-sternal discomfort & \\
\hline
\end{tabular}

Table 4 is regarding awareness, practices, problems, infections and consciousness and custom effects on rest family members due to air pollution. The results obtained through questionnaire survey showed that majority of labor are adapted to air pollution and neglected the safety instruction directed by concerned sections. Almost all industries were operated around the whole day and without following any air pollution instructions; the higher percentage (93\%) of employees were annoyed of air pollution in first eight to ten working hour of the day. The possible reason for being such higher ratio is a higher number of employees and machine working to 
Table 4. Clinical questionnaire

\begin{tabular}{|c|c|c|c|}
\hline & Sl. No. & Questionnaire & $\%$ age \\
\hline \multirow[t]{4}{*}{ Awareness } & $\mathrm{A}$ & Do you have any knowledge of consequence of air pollution? & \\
\hline & i & Yes, I do know that it is harmful to health. & $16 \%$ \\
\hline & ii & I do not know. & $61 \%$ \\
\hline & iii & Yes, I am aware of the effect but why could not we cope with this hazardous issue. & $23 \%$ \\
\hline \multirow[t]{7}{*}{ Safety } & B & What protective measures do you take? & \\
\hline & $\mathrm{i}$ & Yes we do wear mask while on job if it it available. & $5 \%$ \\
\hline & ii & Yes,mask is available but do not wear it & $13 \%$ \\
\hline & iii & It is uncomfortable to wear mask during work. & $25 \%$ \\
\hline & iv & We cannot afford. & $19 \%$ \\
\hline & iv & No. & $17 \%$ \\
\hline & $\mathrm{v}$ & We have no knowledge of such thing. & $21 \%$ \\
\hline \multirow[t]{3}{*}{ Problem } & $\mathrm{C}$ & Any specific time of high air pollution during the day which annoys you more & \\
\hline & $\mathrm{i}$ & Yes Eight to ten hours of morning are more annoying due to air pollution & $91 \%$ \\
\hline & ii & Late hour of the evening are Better & $9 \%$ \\
\hline \multirow[t]{4}{*}{ Diseases } & $\mathrm{D}$ & Do you have any knowledge what types of diseases can caused due to air pollution & \\
\hline & $\mathrm{i}$ & Yes I am aware of the Harmful Effect & $12 \%$ \\
\hline & ii & I do not have any knowledge. & $18 \%$ \\
\hline & iii & Yes I know cough, asthma. Other respiratory diseases. mostly we have & $70 \%$ \\
\hline \multirow[t]{6}{*}{ Consciousness } & E & Does air pollution annoy you? & \\
\hline & $\mathrm{i}$ & Yes. & $20 \%$ \\
\hline & ii & No. & $13 \%$ \\
\hline & iii & Yes, I am on medicine due to Pollution. & $2 \%$ \\
\hline & iv & Yes,it is annoying but we neglect it due to less resources. & $22 \%$ \\
\hline & iv & Now I am use to this environment so it don't bother me. & $43 \%$ \\
\hline \multirow[t]{5}{*}{ Custom Effect } & $\mathrm{F}$ & Do you have any inherited disease? & \\
\hline & $\mathrm{i}$ & No. & $30 \%$ \\
\hline & \multirow[t]{2}{*}{ ii } & Yes,Blood pressure diabetics etc. & \multirow[t]{2}{*}{$65 \%$} \\
\hline & & It is not because of air pollution. & \\
\hline & $\mathrm{i}$ & Yes, we fall ill occasionally but no inherited disease. & $5 \%$ \\
\hline
\end{tabular}

compete for the production rates. Since many industries had no any safety department and same have insufficient safety paraphernalia, the more substantial number (70\%) of the employee were not aware of air pollution safety instructions and led them to become habitual (61\%) of it. During this research, the researcher efforts to find health effects of the labor's, theirspouse due to severe air pollution affection of worker working in the industry. The majority family members (65\%) find health defect. The clinical survey conducted in this research is illustrated in Table 5. The result obtained through this survey highlighted that mostly labor (93\%) is male (98\%) and adult (78\%). As discussed previously that there is no any appropriate safety measure and awareness in labor, most of them visited lately (85\%) to clinics when the situation becomes complicated (80\%). The results highlighted above alarming the health effect of labor due to air pollution and it may directly affect the industries and economy of the country as the work force is considered the backbone.

The main reason is long-term air pollution exposure, continues working hours for month after month and year after year. Because of industries SITE Area, Hyderabad is working 24 hour by 12 hour shift 
Table 5. Survey questionnaire regarding hospital/ clinical

\begin{tabular}{|c|l|c|}
\hline Sl. No. & \multicolumn{1}{|c|}{ Questionnaire } & $\begin{array}{c}\text { Percentage of } \\
\text { Response }\end{array}$ \\
\hline A & What Age Mostly Suffer? & \multicolumn{1}{|c|}{} \\
\hline (i) & Mostly children. & $1 \%$ \\
\hline (ii) & Mostly adult. & $78 \%$ \\
\hline (iii) & Mostly Aged. & $21 \%$ \\
\hline B & How frequently they visit due to that? \\
\hline (i) & Yearly. & $2 \%$ \\
\hline (ii) & Half Yearly. & $85 \%$ \\
\hline (iii) & Monthly. & $2 \%$ \\
\hline (iv) & 3 Monthly. & $10 \%$ \\
\hline (v) & Weekly & $1 \%$ \\
\hline C & At what stage of disease patient come to hospital? \\
\hline (i) & $\begin{array}{l}\text { Mostly when they are at } \\
\text { complicated stage. }\end{array}$ & $80 \%$ \\
\hline (ii) & Vague symptoms. & $3 \%$ \\
\hline (iii) & Early stage. & $5 \%$ \\
\hline (iv) & $\begin{array}{l}\text { Early stage but does not follow } \\
\text { medical advice. }\end{array}$ \\
\hline D & Most affected Gender? & $12 \%$ \\
\hline (i) & Male & \multicolumn{2}{|c|}{} \\
\hline (ii) & Female & $98 \%$ \\
\hline E & Occupation of the patients? \\
\hline (i) & Laborer & \multicolumn{2}{|c|}{} \\
\hline (ii) & Office employees & \multicolumn{2}{|c|}{} \\
\hline
\end{tabular}

\section{Recommendation}

Installation of latest machinery/equipment will results marginal improvement to environment and simultaneously reduces the health hazards. To control air pollution use of APC Devices like chemical scrubber and gas scrubbers, even though installation would be costly but nothing is more valuable then the hazard free life of human being/Mankind. In addition to it, some below recommendations are necessary to follow in the industrial area of SITE Hyderabad.

1. The scrubber systems must be installed at exhaust outlet of the industry to reduce the air pollution.
2. Those industries that produce more Air Pollution should relocate to open spaces away from the populated area.

3. Follow the Limits of the air pollution.

4. Labors and nearby residents should be aware of adopting Personal Protective Equipment's (PPEs).

5. Private (non-governmental), non-private (Governmental) and NGOs should respond appropriately to regulate Air Pollution in these areas.

6. Plant more trees as they are suitable air pollution absorbents.

7. Use Proper Lubrication and Better maintenance so they equipment production less air pollution.

\section{Conclusion}

It is suggested in many surveys and studies that air pollutants are the reason to develop a disease of airway inflammation and aggravate respiratorily and causing different diseases such as a $24 \%$ cough, $18 \%$ Dermatitis, 8\% Exacerbation of asthma etc. To ensure for avoiding such harmful effects due to air pollution, the industries must follow some recommendation such as to follow PPE, increase the rate of Plantation and trees and to install Air Pollution Control Devices (APCD) scrubbers systems to controls the air pollution with in standards limits.

\section{References}

1. Panhwar MA, Memon DA, Aqeel Ahmed Bhutto, Qadir Bakhsh Jamali. Impact of Noise Pollution on Human Health at Industrial SITE Area Hyderabad, Indian Journal of Science and Technology. 2018; 1(31):1-6. https://doi. org/10.17485/ijst/2018/v11i31/130436.

2. Jiang X, Mei XD, Feng D. Air pollution and chronic airway diseases: What should people know and do? Journal of Thoracic Disease. 2016; 8(1):E31-40.

3. Adel Ghorani-Azam, Bamdad Riahi-Zanjani, Mahdi Balali-Mood. Effects of air pollution on human health and practical measures for prevention in Iran, Journal of Research in Medical Sciences. 2016; 21(65). https://doi. org/10.4103/1735-1995.189646. PMid: 27904610, PMCid: PMC5122104.

4. Ambient air pollution: A global assessment of exposure and Burden diseases. Date accessed: 2006. https://apps.who.int/ iris/handle/10665/250141. 
5. Public health, Environmental and Social Determinates of health (PHE). Date accessed: 2014. http://www.who.int/ phe/eNews_63.pdf.

6. Ambient Air Quality Monitoring 5 - Year Network Assessment for Mecklenburg County Air Quality. Date accessed: 2015. https://www.mecknc.gov/LUESA/AirQuality/ EducationandOutreach/Documents/2014HealthEffects.pdf.

7. What are the Health Effects of Air Pollution during Travel? Date accessed: 2013. https://www.iamat.org/blog/what-arethe-health-effects-of-air-pollution-during-travel-3/.

8. In 1952 London, 12,000 people died from smog - here's why that matters now. Date accessed; 16/12/2017. https://www.theverge.com/2017/12/16/16778604/ london-great-smog-1952-death-in-the-air-pollutionbook-review-john-reginald-christie.

9. Iain J. Beverland, Geoffrey R. Cohen, Mathew R. Heal, Melanie Carder, Christina Yap, Chris Robertson, Carole L. Hart, and Raymond M. Agius. A Comparison of short-term and long-term air pollution exposure associations with mortality in two cohorts in Scotland, environment health perspect. 2012; 120(9):1280-85. https://doi.org/10.1289/ ehp.1104509. PMid: 22674867, PMCid: PMC3440112.

10. Vinay Singh Chauhan, Bhanumati Singh, Shree Ganesh, Jamshed Zaidi. Air quality status of commercial and sensitive area of Jhansi City, Bundelkhand, U.P, India, International Journal of Advanced Scientific and Technical Research. 2013; 3(6).

11. Roseline RA, Devapriya M, Sumathi P. Pollution monitoring using energy efficient routing in wireless sensor networks, International Journal of Emerging Trends and Technology in Computer Science (IJETTCS). 2014; 3(1).

12. David Q. Rich. Accountability studies of air pollution and health effects: Lessons learned and recommendations for future natural experiment opportunities, Environment Int. 2017.

13. Ling SH, Eeden SF. Particulate matter air pollution exposure: Role in the development and exacerbation of chronic obstructive pulmonary disease, International Journal of Chronic Obstructive Pulmonary Disease. 2009; 4:233-43. https://doi.org/10.2147/COPD.S5098. PMid: 19554194, PMCid: PMC2699820.

14. Karolina Maduna1 / Vesna Tomašić 1 Air pollution engineering. Date accessed: 2017. https://www.fkit. unizg.hr/_download/repository/\%5BPhysical_Sciences_ Reviews\%5D Air_pollution_engineering.pdf.

15. Chuan CL, Penyelidikan J. Sample size estimation using Krejcie and Morgan and Cohen statistical power analysis: A comparison, Jurnal Penyelidikan IPBL. 2006; 7(1):78-86. 